\title{
Guilt as Condition of Civil Legal Responsibility
}

\section{Gainee Omirzakkyzy Serim}

\section{Sabyr Ashirbaevich Tumenbaev}

\author{
Darkenbaev Askhat llyasovich
}

Kazakh National University named after al-Farabi, Kazakhstan, Almaty, av. al-Farabi, 71

\section{Doi:10.5901/mjss.2015.v6n6s1p487}

\begin{abstract}
This article discusses some questions of guilt as condition of civil legal responsibility. Category of guilt in obedience to the theory of right, provides its inclusion in the category of offenses. Offense is expressed in certain actions (inaction), with specific external signs that show the connection between the offender and the community, causes negative effects of crime and public danger. Guilt is a condition civil responsibility for breach of obligations, and the base is the responsibility of nonperformance or improper performance of obligations, in other words, a civil offense. A legislator specifies the forms of guilt in the civil code, but by general rule they do not have influence on property responsibility of debtor. If a criminal law straight takes into account the forms of guilt and weight (degree) of guilt at punishment, then in a civil law this rule does not carry general character, and is only used in the special norms. Thus authors come to a conclusion that finding solutions to theoretical questions of guilt in civil law has direct impact on finding solutions to practical problems of law enforcement.
\end{abstract}

Keywords: civil legal responsibility, guilt, offence

\section{Introduction}

The perspective of guilty is most sharply considered through a prism of a current state of civil-legal institutes, in particular institute of civil responsibility as mechanism of protection property and personal non-property rights of natural and legal entities. Explanation of questions on guilty and its forms in civil law positively influences essence of civil responsibility so, the matter will be how successfully resolved, also depends efficiency of the civil-legal responsibility.

Guilty possesses the dual (dualistic) contents. On the one hand, it acts as the social phenomenon, with another as the phenomenon psychological. Its social contents consists that it expresses negative attitude of the offender to interests of society and vice versa, and psychological - in need of understanding by the offender of feeling of a personal responsibility and negative assessment of the actions.

Relevance of research in the specified area is caused need of legal practice for the formulation mechanism, establishment and effective application of conditions (one of which is guilty) civil-legal responsibility at its realization. It is important, according to authors, a ratio of these conditions among themselves and their interference. The current state of this problem assumes that it has to be solved according to the dualistic feature of guilty stated above, that is one-sided approach to the solution of this problem will output its one-sided formulation. The integrated position, according to authors, will most fully reflect all essential moments of the considered problems in the spirit of compliance of relevance of research.

\section{Method}

In writing this article by authors were applied the following scientific methods: dialectic, system analysis, comparisons and analogies, comparative-legal, historical-legal, logical. On the basis of a comparative and legal method the essence of guilt in standards of legislations of foreign countries and owing civil legislation. Also this method allowed to carry out the analysis of the developed formulations guilty for civil and criminal law. On the basis of a historical-legal method the authors of article carried out work on research of genesis of guilty at various stages of its existence in relation to a legal component of this term.

The integrated approach allowed to approach the considered problem in a complex and to reveal essence of guilty in interrelation with psychological and philosophical aspect of the contents. This approach, according to authors, most 
fully and objectively reflects specifics of a question, and resolves situations with a problem of an unilaterality and scientific "narrowness" in approaches to the formulation of scientific-legal concept.

Application of inductive and deductive methods rendered effective assistance in process of detection of regularities of development and properties of guilty, and to allocation of such forms guilty, as simple non-execution of the obligation and an inadequate execution of the obligation as driving forces at establishment of degree of guilty. Using a hypothesis method, first of all, allowed to make some of hypotheses and on the basis of it to allocate and to investigate subproblems within the most scientific problem.

\section{Results}

The theoretical importance of scientific work is defined by that, first the authors, designating a guilt problem as paramount in the scheme of conditions civil responsibility, secondly authors of article, conducting this research, tried to fill legal vacuum which existed in the civil legislation, in the sphere definitions of the category "guilty".

The practical importance of research defined by opportunity applications of its results in legislative and jurisprudence, and also teachers of higher educational institutions of courses: "Civil law" and to civil-legal disciplines to specializations. Practical recommendations which are made by the authors of the article, demand their entering into the civil law and giving to it, thereby, the real validity. Legislative fixing of the specified offers will render a positive effect in scope of application courts practically reasonable provisions that, certainly, positively influences on realization of uniform jurisprudence.

Thus, inadequate execution of the obligation can be two forms: incomplete execution of the obligation (simple imprudence) and execution of the obligation with unreasonable risk of approach of the negative consequences (rough imprudence).

The categories " guilty degree" in a civil liability law the concept "form of non-execution of the obligation" (the simple is identical non-execution or inadequate execution of the obligation). Form non-executions of the obligation (guilty degree) in the civil obligations the right there is a dynamic component of guilty established on the basis of all circumstances of non-execution or inadequate execution of the obligation, which represents the quantitative and qualitative characteristic the relations between illegal act and the caused damage. Degree guilty plays a role at a responsibility individual.

\section{Discussion}

Concept "offence" as founding of responsibility, including certain signs, was firmly folded in the criminal, administrative and general theory of right. Concerning formulation of civil offence there isn't single opinion in science, and there is not a legal concept of civil offence. In 1912 G.F. Shershenevich called offense under a civil liability and allocate conditions bring the person to justice: ill effect, causing property damage, violation of subjective rights and the offender's guilt. In obedience to the theory of right every legal relationship arises up because of legal facts. Facts are two kinds: events and actions. Actions, in turn, are legitimate and illegal. When the question is about a wrong act, then it is talked about offence that is the anti-social phenomenon, causing to society well-known harm and pursued by a law. Consequently, a concept "offence" embraces such categories as "misconduct" both a "crime" and difference of them consists of higher degree of crime, and also his public danger.

In composition, both crime and misconduct guilt is present - as a subjective side of act. Guilt in all cases comes forward as an intellectual, volitional moment, but this factor shows up in crimes and misconducts differently. If in a crime the outline of guilt is traced as a subjective side and her role is visible in an act, then in misconducts on the first plan not personality attitude goes out toward the process of act, and attitude toward a result that practically is always related to the property (material) aspect (Shershenevich, 1907, pp.570-580).

It seems that the focus on offense and its elements is justified by the fact that guilt is always associated with a person (legal or natural), then there is a guilt as the phenomenon does not exist in itself, its existence and form always imply its carrier. And other aspects - offense acts as a result of illegal actions (inaction) of a subject that clearly shows the relationship of these elements. Category of guilt in obedience to the theory of right, provides its inclusion in the category of offenses. Offense as stated above is expressed in certain actions (inaction), with specific external signs that show the connection between the offender and the community, causes negative effects of crime and public danger. These signs form are the objective side of offence. These include: illegality, harm existence, relationship of cause and effect. Illegal action is characterized by the special personal and strong-willed relation of the subject - his guilt. It is possible to tell that it is about the subjective party of an offense. Further we will specify that any offense is directed on concrete object. As a 
result of such influence the subject breaks material and non-material interests, both persons, and the states, and societies in general.

Therefore, we designated offense elements (the subject, the subjective part, object and the objective party) which in total form structure of an offense. Interestingly, that in the different fields of law influence of these elements is different: in a criminal law presence all elements of offence necessarily and there is their clear analysis, in distinguished disciplinary responsibility as a basic element subjective side, it is accordingly possible to suppose that in civil liability the object of offence goes out into first place.

As the follower of this concept also S.S.Alekseev who considered acted that "the basis of civil responsibility is the structure of an offense" which is formed by set of the general, typical conditions (elements). Cash of the specified elements is obligatory condition for accountability of the subject of an offense. But not all civilians agree with this concept. Some authors critically approach this position, specifying that distribution on the civil relations of provisions of criminal law about corpus delict, introduction into the civil law having century traditions of criminal and legal doctrines alien to it" is unreasonable" (Alekseev, 1958, pp.47-53). The basis of civil responsibility, according to V.V.Vitryansky and M.I.Braginsky, the result of violation of the subjective civil rights and as civil responsibility addresses as responsibility of the violator the victim is, its purpose is restoration of the violated right (Vitryansky, 2002, pp.722-733). But in civil legal relationship situations when the offense occurs without guilt of the subject (delictual obligations, responsibility for guilt of the third parties) are possible, and it generated emergence of the concept about the truncated structure of an offense which remains disputable and to this day. Yes, it is undoubted, the point of view of V.V.Vitryansky and M.I.Braginsky about the uniform and general basis of civil legal responsibility - violation of the subjective rights deserves attention. But we emphasize that this position involves ignoring the concept of the offense, implying as its constituent elements of the offense of the civil, administrative or disciplinary offense.

Thus, the designation of the offense and its definition as a basis of liability demonstrates the unity of legal liability, the constituent elements of which are - criminal liability, civil liability, administrative and disciplinary responsibility. Whereas, if you follow the point of view of V.V.Vitryansky and M.I. Bragin, civil liability will act as a kind of detached category outside of legal liability, and it is at least contrary to theory of the right.

G.K.Matveev suggested to consider as a basis for civil liability of the composition of the offense, including a set of objective and subjective elements. Among the objective elements include: illegal behavior, its result and the causal relationship between them; the subjective element is the guilt of the offender. G.K.Matveev underlines that in the absence of one of these elements can't come responsibility. But in this case there is a natural situation connected with the existence and definition not guilty responsibility.

In the study of the essence of civil liability can be concluded that a defining feature is its additional burden offender. In accordance with this, and payment of a penalty, and the damages are measures of responsibility, as they have features of complementarity and burdensome to the estate of the offender. Therefore, irrespective of guilt of the offender a duty to compensate the done harm will be civil legal responsibility as possesses its necessary sign and this essential moment is contrary to G. K. Matveev's proposal to consider without guilty responsibility - a duty to compensate harm (Matveev, 1951, p.311).

S.S.Alexeev offers considered as evidence of a tort object, the subject of the offense and its objective side (illegal actions of the offender, the result of a malicious and a causal link between them) and thus setting their presence, to talk about the application of measures to face civil responsibility. It does not include guilt in the number of mandatory elements of the offense, and it is said to more accurately reflect the specifics of liability in civil law (Alekseev, 1972).

In the context of this problem raises the question of the relationship between the concepts of "base" and "condition" civil responsibility. G.K. Matveev, as we pointed out above, admits guilt basis for civil responsibility (Matveev, 1951). M.I. Braginsky and V.V. Vitryansky act with the view that the basis civil responsibility is an offense, and "a prerequisite for attracting the debtor to liability for breach of the obligation is the guilt of the debtor" (Vitryansky and Braginsky, 2002, p.721).

Guilt is a condition civil responsibility for breach of obligations, and the base is the responsibility of nonperformance or improper performance of obligations, in other words, a civil offense.

Emphasizing the universality of guilt as a condition of legal liability in the criminal and civil law, come up against the need for a comparative legal analysis of this category to reveal the specifics of guilt in the criminal and civil law. Guilt as the most generalized concept comes as a result of those actions which are contrary to the rules and principles of conduct. But we point out that fault - concept itself abstract, because it manifests itself in specific actions in the form of intent or negligence, and it is important that provision. And thus, the absence of the wording in the criminal law concept of "guilt" is not understood by us as the omission of the legislator, and as self-evident phenomenon. However, on the other hand, the nature of guilt and clarification of the significance of its formulation as a concept, it is important for the criminal 
jurisprudence, as well as for civil science. In the science of criminal law, most legal scholars as the main identify two concepts of guilt, psychological and estimated. In turn, the estimated concept of guilt is divided into two subspecies. According to S. Sklyarov, "in the first instance as a theory estimated of guilt is treated by a court assessment of objective and subjective circumstances related to the crime. The second - a guilt is understood moral - political assessment of the offender in terms of class positions " (Sklyarov, 2003, p.71).

The concept of guilt is not taken root in modern criminal law, because "it has advanced along with the narrow notion of guilt as the mental attitude of a person to have the deed and the broader concept of guilt - as the basis of criminal responsibility. Thus under guilt as the basis of criminal responsibility, it means the totality of the circumstances deserving, the conviction of the court, the negative (moral and political) assessment on behalf of the state " (Filimonov, 2004, p.69).

Essential to our attention is the psychological concept of guilt because, firstly, it is dominant in modern criminal law, and, secondly, the psychological interpretation of guilt is also problematic part of this study. But in this concept is no unity in the approaches to the determination of guilt. Here, for example, determines guilt V.A.Jakushin " guilt - in his opinion - is the mental attitude of a person to commit socially dangerous and criminally wrongful act is expressed in certain statutory forms that reveal the connection of intelligent, strong-willed and sensory processes of the psyche and the act of a person is by virtue of this base for subjective imputation, qualification of the offense and determine the limits of of criminal responsibility" (Jakushin, 1988, p.122). But another lawyer - A.V.Naumov, understands by guilt the mental attitude of a person to commit them socially dangerous act and its consequences in the form of intent or negligence (Naumov, 2000, p.223). There is also a view that the guilt - is prohibited by criminal law, mental, in the form of intent or negligence, the attitude to face it commits a socially dangerous act and its consequences (Krieger, 1988, p.125).

Interestingly determination of guilt at V.V.Lunev, which defines it as mental attitude to face it commits public danger acts, its socially dangerous consequences and other legal relevant circumstances of the crime (Lunev, 2000, pp 10-12).

In recent years the study of guilt in the criminal law has been given attention. Of course it is connected primarily to the fact as mentioned above, that the criminal law so far as well as in civil, there is a gap in determining guilt on legislative level. V.A.Nersesyants proposes to designate as guilt "mental attitude of a person to commit them to public danger act provided for in criminal law, determined appropriate form" (Nersesyants, 2000, p.59). Undoubtedly interesting are the provisions of the guilt developed a European criminal law theory, given the fact that these provisions could have a significant impact on the elucidation of questions about guilt, considered the national criminal and civil science. Besides, the European and The Patriotic legal systems, as we know, belong to a single (continental) law system, which is important. In the European criminal law literature formed the view that approaches in which guilt was determined to psychological positions, at least, no longer meet the issues of guilt in the matter of establishing its definitions. Place of psychological concepts in determining guilt took the normative theory. Here are the views of prominent researchers of this problem. Professor Wessel wrote that the psychological definition of guilt saw it in nature subjectively mental (psychological) regarding criminal to act, is identified with guilt mental processes ("Aware - not aware of," "anticipate - not anticipate", "desire - not desire "). Thus, the psychological concept deals with the essence guilt in the context of intent or negligence. In contrast, consistently considered early in the century, Professor Frank normative doctrine guilt provides that the nature of guilt lies in the blameworthiness will, in other words, the regulatory mental component elements (Wessels, 1985, p.107). In a similar perspective, reasoned and S.Shipani, stressing that: "Guilt implies reproach which makes a man, a reproach, which expresses a negative judgment about his behavior" (Schipani, 1969, pp.106-107).

Another luminary of the European Criminal Law - Professor Lenkner, pointed out that the reasons for the transition to the regulatory definition of guilt is not random, but quite reasonable and can be explained in terms of the natural development of the doctrine of the guilt. That is, the process involves the consideration of the change of the vector nature of guilt with its formal characteristics, to the characterization of it as a material thing by filling the content of the concept category of "public danger". Thus, derived on the basis of the definition of guilt will not reflect the characteristics of the mental processes of the person, and normatively specified processes to his bad conduct and, therefore, meet the requirements of the law, filling, thus, the existing legal vacuum. How correctly emphasizes Professor Lenkner if not agree with normative understanding of guilt, respectively, should not agree with the normative definition of the crime, as a more general concept that includes guilt (Lenckne, 1972, pp.35, 45, 54). Interestingly remark of Beshyutts that indicated on the discussion about the guilt that German law did not develop in the legal sources of the unified concept of guilt.He also emphasized on the relationship of guilt in the civil law, that the criterion for determining how the guilt and the case serves such a thing as "will". As for the case, which we now define negligence, they did not find their legal significance and features of the account, and explained except as a typical situation (Beschütz, 1907, pp.147-148).

But, as we know, the domestic criminal law theory adheres to the psychological approach to the determination of guilt in contrast to the European science of criminal law. But, nevertheless, the difference approaches should not mean 
no progress investigating the nature of the applicability of guilt in relation to each other. After all, in the end, one goal - to bring such a determination of guilt, which would meet the issues under discussion.

In the matter of determining guilt in criminal law, there are many approaches and concepts. But there are moments that combine the notion of guilt given by various authors. Firstly, the characteristics of fault as a mental attitude of a person to their actions; secondly, the attitude of the person to come consequences; Third, the expression of this relationship through the intentional or reckless actions. It is around these elements are constructed and all existing definitions of guilt in criminal law.

Sure, the analogy in criminal and civil law, in respect of guilt as a condition of liability discover that that the crucial role given to guilt as mandatory grounds of criminal responsibility (along with such mandatory elements of the offense as the subject of the crime, the object and the objective side) justified itself characteristics and nature of criminal responsibility. After all, the responsibility as a legal phenomenon always involves a specific person, thus enables to implement the functions of responsibility, and, in particular, preventive. And if for civil liability characterized by the presence, as the principle of guilt, and the principle of causing, when it is defined, the criminal liability is established only absolutely imperative principle of guilt. Of course, this fact only underlines the principle of justice, which is a fundamental principle in the theory of law. Freedom - is a a major achievement and the value of humanity. Nobody have rights to deny or limit them; about the possibility of imprisonment or restriction can speak only in the cases provided by law.

But it is quite natural question arises: what, then, is the fact of the transformation element of guilt in civil responsibility? And if the criminal law theory does not explicitly admits responsibility for the actions of the innocent, why does it allow civil legal science and the law? Specify that a given formulation of the question, we assume that the guilt is a common element in the design of the offense in the legal responsibility in general. However, the neglect of this fact in the civil law, that is the neglect of liability without guilt, violates absolute human rights too (for example, cases of tort liability when the causer is not responsible for the occurrence of harm). There is clearly detected the contradiction in the fact that an element of guilt in criminal law reflects the subjective aspect of the crime, and is characterized by psycho-volitional processes in the mind of the individual, about absolute subjectivity element of guilt can't speak in the civil law. More objective will be characterization of guilt through the subjective-objective sign, since in the first place is not beyond the personal relationship of a person to the offense, and the onset of the negative result of his activities. However, this fact only indicates a transformation of guilt, but not about its diversity in criminal and civil law.

Referring to the theory of law, we emphasize that the establishment of guilt for an offense is a necessary feature of the implementation of legal liability as a general rule. If you start from the principle of causing liability in the statement, then talk about education, general preventive role of legal liability is not necessary. After all, naturally, that the principle of guilt, being the dominant and fundamental to the responsibilities, creates a deterrent and stabilizing factor in human behavior. Whereas the fact of liability, by general order, according to the principle of causing would lead to chaotic process and leveling of the preventive function of legal liability. If a person is liable for culpable offense, it assumes in its further correction and legal behavior. However, if the person would be responsible in the absence of guilt, this fact would encourage the exact opposite, undesirable for society in general behavior. The exception to this in civil liability cases are tort liability. The value of human life and health should not be called into question, even in the case of absence of the causer of guilt. In the process of the genesis of guilt and its original definition and establishment of the conditions of civil liability, its role was different. In the early stages of development of civil rights (pre-classical period of Roman law) the need to establish of guilt for the prosecution did not exist. That is the very fact of the injury involved the sole responsibility in this regard, according to the principle of retaliation. However, in the classical period of Roman private law elements present in the actions of the offender's of guilt attached special importance, and has established itself as an axiom position that "there is no-fault liability."

Conducts studies of guilt and its role in the establishment of responsibility, we always come up against the dependence of these studies of concepts such as the principle of causing and the principle guilt.

Liability may be contractual and non-contractual, and the principle of causing implemented in non-contractual liability. Accordingly it can be said that the principle of guilt meets contractual liability. A characteristic property of guilt is that a contractual liability, the person signing the contract implies that each party to meet its obligations, and in the case of non-compliance if found guilty, will be held responsible. Failure to take all measures for the proper fulfillment of obligations, as well as performance of an obligation with the degree of care and diligence which is required by the nature of the commitments implies thereby guilty person.

The mechanism of non-contractual liability is inherently involves noncompliance assumed any concrete commitments and thus liability in the manner provided for in the contractual liability; non-contractual liability is realized from the very fact of the injury. "Tort liability is not preceded by any obligation of a particular person. It is based on the fact that an action that infringes on the absolute rights: the right to property, life and health of citizens" (Belyakov, 1986, 
p.25).

Talking about the occurrence of civil liability only if you have specified in the law or in the contract bases. Here, as an alternative to the parties have to choose other bases of liability. This is primarily due to the specific assumed by the parties obligations. For example, the parties issued a contract for the supply of goods, the buyer paid the deposit. The seller must deliver the goods at the agreed place, but along the way the product was accidentally damaged. The question arises of liability. Unless otherwise provided by the contract, such as the ownership of the goods passes at the time of prepayment, then the seller must return the amount of money paid by the buyer. In this example, the element of guilt is present, and if the seller specified in the contract when the ownership, above, to talk about his responsibility would not have to. And because this position did not mark that, according to a law, when the right of ownership goes across in the moment of transmission of commodity, salesman and bears the responsibility before a customer (Aristov, 1997, p. 26).

Therefore, the above designated base attack civil liability for breach of the obligations which are: non-performance or improper performance of obligations, and other reasons, which are provided by the parties in the contract. Question about elimination or limitation of liability for willful violation of the obligation is governed by the law mandatorily, and agreements with such condition shall be deemed null and void.

Speaking of the modern doctrine of civil law in the first place, it must be said that the main guilt of the basic provisions of which have been developed by the Roman law, and later development of the Russian and Soviet jurist base foundation of existing civil law and claim the continuity of the legal provisions.

The issue of guilt became the subject of many monographs, see the light of recent (Pavlova, 1984; Plotnikov, 1993; Dmitriev, 1996; Khokhlov, 1998). In particular this is how determines guilt E.V.Butenko: "Guilt of the debtor in violation of a contractual obligation - is expressed in the outside deliberately or inadvertently such a will of the debtor, which is different from his will, fixed in the contract, and which led to the failure to take them all possible with the necessary care and diligence measures than entailed a violation of a contractual obligation " (Butenko, 2002). And as G.F.Tselnicker understands guilt: "Guild of individuals - is consciously willed attitude toward wrongdoing and its consequences in the form of intention and negligence. In other words, it is set in a civil law, that "person ... bears the responsibility at presence of guilt (intention or carelessness)..." (Tselnicker, 2004).

Thus, M.I.Braginsky and V.V.Vitryansky imply that the guilt - it's not compliance (with intent) or incomplete compliance (if inadvertently) the degree of care and diligence in the performance of the obligation, what is required of a person by the nature and conditions of the obligations of the turnover, while not taking them (face) of all measures proper execution obligations. (Vitryansky and Braginsky, 2002, p. 721).

Do these formulations of guilt, following from a law (in obedience to M.I. Braginsky and V.V.Vitryansky) to the range of problems of guilt and carry exhaustive character, answer? An answer appears ambiguous.

We will try, neither rejecting psychical moment in determination of guilt nor critics of such conception, to bring the integrated (more, as us it seems to, universal) determination over of guilt.

A modern civil legislation, as we know, regulates the property and related to them personal unproperty relations. In swingeing majority of cases the article of adjusting are property relations. It seems, that round these relations formulation of guilt must be built, from one side, and, on the other hand, the participants of these relations (legal and natural persons) come forward active, volitional (principle of freedom of agreement, freedom of will) subjects, it is exactly entered the active actions into legal relationships, change or stop them. Thus, we can distinguish the property-volitional component of this system.

Does not cause a dispute and that guilt as a legal category is related to such properties as unlawful and intention or carelessness, about what was mentioned before. And as a fact, to guilt the offensive of negative consequences is related for a disinterested herein person.

Taking into account all of it, it is possible to show out determination of guilt, that does not apply on absolute universality, but, it seems, reflects problem moments in her determination.

So, guilt in a civil law is the volitional relation of person, expressed by property interests, to the unlawful actions (inaction) that caused harm to other person.

Guilt can come forward in form intention or carelessness. A legislator specifies the forms of guilt in the civil code, but by general rule they do not have influence on property responsibility of debtor. If a criminal law straight takes into account the forms of guilt and weight (degree) of guilt at punishment, then in a civil law this rule does not carry general character, and is only used in the special norms. There is a point of view, that as it applies to determination of intention and carelessness in a civil law (because a civil code does not formulate these concepts) it is needed to come from the criminal law constructions of determination of intention and carelessness (Kiselev, 2000, p.25). So, according to criminal law science determination of intention as it applies to a civil law will look like the following: civil offence confesses perfect with direct intention, if a person realized wrongfulness of the actions (inactions), foresaw possibility or inevitability of their 
negative consequences and wished their offensive. Although the presence of direct intention in civil liability is not widespread and meets rarely, eliminating him is impossible. Such case can exemplify, when a person buys on a credit commodities without intention in the future for them to disburse.

As it applies to indirect intention, determination will look so: civil offence confesses perfect with indirect intention, if a person realized wrongfulness of the action (inaction), foresaw possibility of offensive of negative consequences, did not wish, but consciously assumed these consequences or behaved it is indifferent to them. The cases of indirect intention are widespread in contractual relations.

On the same construction determinations of carelessness will be built: a person that foresaw the offensive of negative consequences from his illegal actions operated with a rough carelessness, but without sufficient to that grounds presumptuous counted on their prevention.

By a next general sign, both crime and misconduct guilt comes forward - as a subjective side of act. Guilt in all cases is characterized the presence of intellectual, volitional moment, but this moment shows up in crimes and in misconducts differently. If in a crime a subjective side is traced and her role is visible in an act, then in misconducts on the first plan not personality attitude goes out toward an act, and attitude toward his result, that practically is always bound by a property (material) aspect. About it yet wrote almost 100 years ago by G.F. Shershenevich, specifying on family connection of misconduct and crime.. Here, in particular, that he marked: "As an unauthorized action, civil offence, approaches a criminal crime that also is an action unauthorized, under penalty of punishment. How then, and another may be committing a prohibited or omission that should have been performed. Both unite in a general concept about offence. Civil offense and criminal offense are two sides of the same phenomenon. One and the same action affects both the public interest and private property interests.

There is a view that the indication of guilt forms dictated not so much from a practical point of view, how to indicate the general nature of guilt in the criminal and civil law.

As is known, the courts determine the type and amount of punishment on the basis of all the circumstances of the case. Civil Code only outlined the form of guilt, pointing out that any person has a right to full compensation for damages if their rights are violated. Courts should be guided in their decisions the principle of fairness and objectivity, it means the judge makes his decision based on all the circumstances of the case, based on the personal point of view in accordance with the letter of the law, and it would, at least, is wrong to say that at one and the same tort, which resulted in damage occurred, but in different forms of guilt, the Court's opinion will be the same in both cases, although the penalty for the offender will be the same as if intent or negligence when, as the law required. Probably more appropriate here to talk about the use of the court for the offender in the case of deliberate guilt additional burdens. It seems that the designation forms of guilt in the Civil Code - a direct opportunity for the court proceedings in their legal maneuvering in determining punishment. Moreover, the presence of a deliberate form of guilt in tort, as mentioned, is very rare in comparison with criminal offenses where intentional acts of wine, figuratively speaking, "locomotive" of criminal behavior.

V.V. Vitryansky and M.I. Braginsky indicate that in the civil law, there are three forms of guilt: intent, negligence and gross negligence; intentional guilt, in their view, expressed in intentional actions (inaction) of the debtor that mediate non-fulfillment or improper fulfillment of obligations, or the impossibility of its fulfillment (Vitryansky and Braginsky, 2002, p.758). The main guiding of intent here is principle and deliberate guilt. It seems that the further division of intentional guilt (direct and indirect intent as in criminal law) is not suitable in the civil law, because he (indirect intent, characterized by a conscious assumption of the consequences or indifference to him) ultimately does not imply that the losses will be less than they could be in direct intent. Specifying that such subjective criteria as "conscious assumption consequences" and "indifference to negative consequences," have no effect on the objective unavoidable negative consequences for disinterested in the person who dictated the main and decisive factor for the offender - his deliberate behavior. As for the guilt of the debtor in the form of negligence, it "is present in cases where the debtor is the performance obligation does not show the degree of care and diligence, what was required of him by the nature of the obligations and conditions of traffic, and as a result of him not to take all appropriate measures for the proper performance of an obligation". As seen here there is no element of intent in the actions of the person, that is, the behavior is not consciously directed to the offense, but at the same time the behavior of the person is absent due care and diligence. We can say that a person exhibits some prudence and care, but not enough to avoid offense and negative consequences.

The degree guilt as a factor influencing the determination of the amount of liability under civil law is taken into account, if this is specified in the rule of law. That is, this provision is a special character. The legislator does not determine the degree guilt, just as of the guilt. The degree guilt was mentioned even in Roman law. The degree guilt determined by the degree of the negative attitude of a person to the interests of individuals, society, manifested in the crime. The degree guilt of a particular person in the commission of certain crimes is the direct expression of the distortion measure of value orientations of the perpetrator. Given that the degree of guilt is a quantitative expression of a negative 
attitude to the interests of individual persons society, as well as an indicator of the distortion value orientations of the guilty, establish its causes different measure of censure person measure it responsibility. Determining whether the degree of guilt promotes objective decision the question of responsibility and blameworthiness of the guilty.

\section{Inference}

Guilty is multidimensional phenomenon which is characterized by a versatility of approaches of its definition. From the point of view of the right, guilty - the personal attitude of the offender towards results of the action having a legal consequence.

In relation to civil law definition of guilty will look as follows: guilty in civil law - the strong-willed relation of the person expressed by property interests to illegal actions (inactions) which did harm to other person. The guilty expressed in the form of intention or imprudence. In relation to obligations in civil law the concept "deliberate guilty" corresponds to the concept "simple non-execution", and consists in understanding and deliberate actions (inactions) of the person which are entirely directed on the non-execution of the obligation causing damage to the person who isn't interested in it. For the concept "imprudence" in a civil liability law the concept "inadequate execution of the obligation" is equivalent, and there is at actions (inactions) of the person if he not completely adhered to those developed and (or) established rules of the obligation, though had such opportunity therefore there was an offense.

In criminal law, as well as in civil, there is no legislative definition of guilt, and this fact is the uniting provision of a perspective of guilty in the right in general. However, distinction that in civil legal responsibility there is a certain transformation of an element of guilty in comparison with its criminal-legal characteristic. There is a question: with what it is connected? If the criminal-legal science unambiguously doesn't allow responsibility for innocent infliction of harm why it is allowed by civil-law science and the civil legislation? We will specify that at this statement of a question, we recognize that guilty is the general element in a design of structure of an offense in legal responsibility in general. The fact of possibility of occurrence of responsibility without guilty in criminal law would break set of the natural and absolute rights and freedoms of the person: for example, the person could be deprived of freedom even if he wasn't guilty. However, not accounting of this fact in civil law, that is not accounting of responsibility without guilty too violates absolute human rights (for example, cases of delictual responsibility). Here obviously the contradiction which is that the guilty element reflects the subjective party of a crime in criminal law is found and is characterized by psychological processes in consciousness of the personality. In civil law it isn't necessary to speak about absolute subjectivity of an element of guilty, the characteristic of guilty through "subjective-objective" sign as not the personal relation of the person to an offense, and the come negative result of its activity comes out on top here will be more exact. However, this fact speaks only about some transformation of guilty, but not about its heterogeneity in criminal and civil law.

\section{References}

Alekseev, S.S. (1958). About structure of tort. Jurisprudence, 1.

Alekseev, S.S. (1972). Problems of the theory of law. B.1. Moscow.

Aristov, S.V. (1997). Legal and contractual liability. Terms of the reduction and exemption. Lawyer. 11.

Belyakov, A.M. (1986). Civil liability for causing harm. Moscow.

Beschütz. (1907). The negligence within the historical trends noted in Schuldenere. Breslau.

Butenko, E.V. (2002). Fault in violation of treaty obligations (Dissertation PhD). Krasnodar.

Dmitriev, O.V. (1996). No-fault liability in civil law. (Dissertation PhD). Saint-Petersburg.

Filimonov, V. (2004). Theoretical problems of the doctrine about fault in criminal law. Criminal law. 3.

Jakushin, V.A. (1988). Subjective imputation and its value in criminal law. Tolyatti.

Khokhlov, V.A. (1998). Civil liability for breach of contract. (Dissertation PhD). Samara.

Kiselev, S. (2000). Forms and types of fault in civil matters. RU. 4.

Krieger, G.A. (1988). Soviet criminal law. Moscow..

Lenckner. (1972). Strafe, Schuld and Schuldfahigkeit.

Lunev, V.V. (2000). Subjective imputation. Moscow.

Matveev, G.K. (1970). Bases of civil responsibility. Moscow.

Matveev, G.K. (1951). Fault as the basis of civil responsibility by the Soviet right: Abstract. Moscow.

Naumov, A.V. (2000). Russian criminal law. Moscow.

Nersesyants, V.A. (2000). Careless fault: problems and decisions. State and right. 4.

Pavlova, O.P. (1984). The value of the creditor's guilt civil liabilities. (Doctoral dissertation). Leningrad.

Plotnikov, V.A. (1993). Negligence as a form of guilt in civil law. (Doctoral dissertation). Moscow.

Schipani, S. (1969). Responsabilita "ex lege Aqilia". Torino. 
Shershenevich, G.F. (1907). Textbook Russian civil law. S-Pt.

Sklyarov, S. (2003). Problems definition of guilt in the criminal law of Russia. Criminal Law. 2.

Tselnicker, G.F. (2004). Fault in Russian law (general-theoretical and historical aspects). (Doctoral dissertation). Samara. Vitryansky, V.V., Braginsky, M.I. (2002). Contract Law. B.1. Moscow.

Wessels. (1985). Strafrecht. Allgemeine Teil. 15 Alf. Heidelberg. 